\title{
Effects of Party System Fluidity on Legislative Oversight and Good Governance Indicators (in the context of Sub-Saharan African Countries)
}

\section{AKBIKESH MUKHTAROVA}

Graduate School of Public Policy, Nazarbayev University, Nur-Sultan, Kazakhstan.

\begin{abstract}
While analyzing data for 47 Sub-Saharan African countries, this article explores the correlation between Legislative Oversight and Worldwide Governance Indicators (WGI) and the effects of Party System Fluidity on WGI and legislative oversight. The effects of party systems fluidity on governance indicators and legislative oversight have received little systematic scholarly attention. To fill the gap in the existing literature, the article explores how in/stability of party systems affects governance indicators and legislative oversight capacity in Sub-Saharan African countries. Analyzing the data on 47 Sub-Saharan African countries, we find that legislative oversight has a strong positive relationship with Worldwide Governance Indicators; ${ }^{1}$ however, instability of political party systems expressed in high party systems fluidity has a negative relationship with legislative oversight as well as all six dimensions of WGI. These findings reaffirm: "that the stability of political party systems"2 (Pelizzo: 2020, p. 265) is a crucial factor that is essential for the development of democratic institutions and further evolvement of mechanisms of democratic control of Parliaments over the work of national governments. The work structure is the following: firstly, it analyzes how academic scholarship defines legislative oversight and party system fluidity. The second part presents our data analysis methods. In conclusion, the paper discusses the research's key findings, namely the effects of party systems fluidity on legislative oversight and WGI in the context of SubSaharan African countries.
\end{abstract}

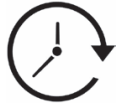

\section{Article History}

Received: 28 July 2020 Accepted: 6 October 2020

\section{Keywords}

Legislative Oversight; Party Systems Fluidity; Sub-Saharan African Countries;

Worldwide Governance Indicators.

CONTACT Akbikesh Mukhtarova 1 akbikesh.mukhtarova@nu.edu.kz 9 Graduate School of Public Policy, Nazarbayev University, Nur-Sultan, Kazakhstan.

\section{(c) (i)}




\section{Introduction}

Academic scholarship draws attention to the problem of declining trust in the institution of political parties worldwide. Reasons for such sowing distrust to political parties might be different: e.g., high dependence of political parties from the state (both legally and financially) rather than from the society $^{3}$ (Van Biezen \& Kopecký, 2007, p.248), the development of new technologies that make direct communication between citizens and the state authorities easier; therefore, the institute of political parties is seen as a somewhat archaic institution. Also, corruption scandals ${ }^{4}$ (Transparency International, 2019) and doubts that political party representatives are lobbying for political elites' interests and large scale business rather than of citizens also further to a decrease in trust to the very idea of parliamentarism and parliamentarian democracy. In developing countries such as Sub-Saharan African countries, an additional concern is related to the emergence of ethnic-based political parties, which in the context of multiethnic societies lead to the emergence of ethnic-based societal cleavages. As the researcher, Kimathi (2010) pointed out:

"Ethnicity, not ideology, determines party loyalty, party affiliation, and ultimately party and political dominance. The ruling class has been able to manipulate ethnicity in such a way as to present its political fortunes as synonymous with those of its ethnic group."5 (Kimathi: 2010, p. 50).

Therefore, political parties serve as an instrument for promoting the interests of those ethnic groups belonging to the "ruling class," while other ethnic groups' interests might be underrepresented.

All these factors, such as corruption scandals involving political parties representatives, ethnic fractionalization, and underrepresentativeness of interests of certain (ethnic) groups within the population, lead to the loss of credibility to the institute of political parties in the eyes of the electorate.

Despite all these negative factors, the Parliament remains the key actor to which the power of holding governments accountable is granted. Instruments of democratic control of the Parliament over the work of national governments are quite comprehensive. They include different legislative oversight tools such as: "hearings in committees, hearings in the plenary assembly, inquiry committees, parliamentary questions, question time, interpellations, and an ombudsman.”6 (Stapenhurst et.al, 2014, p. 290).

Therefore, despite all doubts and suspicion, the role of national Parliaments and their legislative oversight capacities should not be underestimated.

However, reasonable questions may arise as to the extent to which Parliaments in Sub-Saharan African countries use legislative oversight tools? Academic scholarship defines different factors that might affect oversight effectiveness, except political (forms of the government, the level of democracy), and economics (the level of income); also cultural (or contextual) factors such as shared norms, values, traditions, moral may exert influence on legislative oversight effectiveness. ${ }^{7}$ (Pelizzo \& Stapenhurst, 2004; 8 Pelizzo \& Stapenhurst, 2013; ${ }^{9}$ Sartori, 2005). Based on this understanding of the importance of contextual factors, we hypothesize that in/stability of party systems or using ${ }^{10}$ Nwokora \& Pelizzo, 2015) terminology party systems "fluidity" impacts both on legislative oversight as well as on governance indicators.

However, before dwelling our attention to exploring these relationships, it is essential to analyze how academic scholarship defines legislative oversight and party systems fluidity.

\section{Literature Review: Academic Scholarship on Legislative Oversight and Party Systems Fluidity. How academic scholarship defines legislative oversight?}

In Functionalist Theory of Oversight (2015), the researchers Kinyondo et al., stress that communication is a crucial contextual factor, which is essential for oversight and pointing out that communication being a part of the oversight, is:

"an instrument through which the overseer (Parliament) seeks explanation and information from the overseen (Government), through which 
the overseen describes, explains, and ultimately accounts for its actions and decisions to the overseer."11 (Kinyondo, et al., 2015)

Therefore, legislative oversight is seen as a control mechanism and a communication tool between the Parliament and the government.

In their earlier study, Pelizzo and Stapenhurst (2004) Tools of Legislative Oversight and the work dated (2012) on Parliamentary Oversight Tools ${ }^{12 ; 13}$ provide quite a comprehensive overview capturing not just different legislative oversight tools but also the analysis of factors that might affect legislative oversight capacity and its effectiveness; for instance, the form of governance (parliamentarian, presidential, semi-presidential) and the level of democracy and economic factors as income levels.

The academic scholarship differentiates various typologies of legislative oversight tools such as ex-ante and ex-post and internal and external oversight tools. Namely, while introducing the time dimension, ex-ante legislative oversight tools could be considered as instruments used by the Parliament: "before a policy is formulated, legislated, or implemented." ${ }^{14}$ (Chohan, 2017, p. 3). At this initial stage, the Parliament uses oversight tools before specific policies implementation to clarify the government concerning different aspects of these policies. Such ex-ante legislative oversight tools include: committee hearings, questions (in oral and written forms) addressed to the government, etc. while ex-post oversight tools are those instruments of control used by the Parliament when specific policies are already in the process of their implementation or are already along with being implemented, such oversight tools include public account committees and the ombudsman, anti-corruption agencies, along with others. Scholars also classify the same legislative oversight tools as internal and external oversight tools, depending on whether: "the oversight is conducted from within the legislature (the Parliament) itself " or independently of it. ${ }^{15}$ (Ibid, p. 3).

Following this logic, "internal oversight tools"16 (Stapenhurst, Jacobs \& Eboutou, 2019) comprise of: "committees and special commissions of inquiry, review of appointments and power to censure/impeach/dismiss, chamber proceedings: questions and interpellation and plenary, debates." ${ }^{17}$ (Stapenhurst, Jacobs \& Eboutou, 2019, pp. 121-122), while external tools encompass particular external control institutions created outside of the Parliament as Anti-corruption agencies, Ombuds offices, along with others.

In these early works, the researchers focused their attention mainly on the dependence of oversight capacities from various political and economic factors. Stapenhurst and Pelizzo (2004; 2012) have found that oversight capacity (the number of legislative oversight tools) depends on the form of the government (parliamentarian, semi-presidential, presidential) as well as the level of democracy and the level of income of those countries. ${ }^{18}$ (Stapenhurst, et al., 2014)

However, "the form of the government and the number of oversight tools"19 (World Bank Institute, 2013) cannot explain why some countries are more advanced in using legislative oversight tools rather than others. For instance, Gabon and Mali possess seven oversight tools, while Angola just three $^{20}$ (Pelizzo \& Stapenhurst, 2004, pp. 12; 19); all these three sub-Saharan African countries have a semi-presidential form of the government. Thus, this fact signifies that the government's form and other factors might affect oversight capacity and oversight effectiveness.

According to the researchers, the level of democracy impacts oversight potential. The authors found that: "Non-democratic countries have an average of only five oversight tools, while democratic 6.41."21 Ibid. p. 18). At the same time, researchers admit no clear uni-directional causality between the dependent (legislative oversight) and independent variable (the level of democracy); therefore, it is hard to bypass the problem of reverse causality. As one may argue, a more significant number of oversight tools can appear, and function in more democratic rather than in non-democratic countries, as the environment to nurture the potential of legislative oversight is absent in the latter.

Not solely political but also economic factors could affect legislative capacity, namely the level of income. As World Bank Institute specialists underline: "research indicates that legislatures in parliamentary systems, richer and more democratic 
countries are better equipped than those operating in less-democratic, middle and low-income countries with presidential and semi-presidential systems."22 (The World Bank Institute, 2013, p. 19)

Understanding all caveats and problems related to reverse causality, the researchers in their latter studies go beyond this and emphasize that not just a form of the government or the level of democracy but also other factors, e.g., most importantly, availability/ or absence of the political will explains why some Sub-Saharan African countries are more effective in using legislative oversight tools than others.

However, how to measure legislative oversight effectiveness? In A Functionalist Theory of Oversight (Kinyondo et al., 2015) published the article entitled where authors, while profoundly analyzing the question of how to measure oversight effectiveness, emphasized that: "to more adequately understanding oversight effectiveness a multidimensional approach is more appropriate rather than the unidimensional ones adopted in previous studies."23 (Kinyondo, et al., 2015)

The researchers argue that not just political, economic, but also other aspects are crucial. Hence not the number of oversight tools (legislative capacity) but rather the context in which communication is taking place between the overseer and overseen is essential.

In this regard, formal legal provisions like Constitution, legal acts, and informal institutions such as shared values, morals, and traditions are of great importance.

Therefore, the combination of political, economic, and cultural (contextual) factors might influence legislative oversight effectiveness and political party systems development.

While emphasizing that contextual factors are important, we would like to suggest that party systems fluidity influence legislative oversight. However, let us first consider how academic scholarship defines party systems and party systems fluidity (or instability of party systems).
We have mentioned earlier that legislative oversight effectiveness depends on contextual factors between overseer and overseen, e.g., values they share. Political parties could also be considered as institutions formed on shared values. For instance, Leiserson (1958) in Sartori (2005) emphasized that: "parties can be observed as organizational groups, as idea groups and as social groups." ${ }^{24}$ (Sartori, 2005, p. 5).

It's important to mention, Duverger (1954), while focusing on political parties' organizational structure, less attention paid to the party systems or contextual environment in which parties emerge and function. Duverger (1954) was more interested in studies of the inner structure of political parties and suggested different typologies of political parties as:

"associational parties of the loose Gesellschaft type: community like parties of the Gemeinschaft type, and devotee parties of the Bund type."25 (Duverger 1954, 124-32 in Sartori, 2005, p. 7).

Party systems Duverger categorized based on the number of political parties as:" single-party, two-party and multi-party."26 (Novák et al., 2015, p. 69).

Sartori went beyond Duvergers numeric typologies in the classification of party systems and emphasized that party systems can be classified not by a number of parties but rather based on: "the number of "relevant" parties"27 (Novák et al., 2015, p. 70); therefore, Sartori: "succeeded in formulating precise distinctions among different types of multiparty system."28 (Pasquino, 2005, p. 36).

Namely, Sartori (1976) suggested seven types of political party systems ${ }^{29}$ (Nwokora \& Pelizzo, 2015, p. 460), those with one relevant party: such as one party, hegemonic party ${ }^{30}$ (Nwokora \& Pelizzo, 2018, p. 103) and predominant party: with two relevant parties which form two-party systems; and those having more than two relevant political parties, which in their turn also could be classified as: "moderate pluralist party system have between three and five relevant parties, while polarized pluralist party systems have more than five parties." ${ }^{131}$ (Pelizzo \& Nwokora, 2016, p. 1021). 
Taking into account the significance of the contextual factors, Giovanni Sartori, in his pioneering work in the field on Parties and Party Systems (1976), went beyond Duverger's (1954) consideration of the "anatomic structure" of political parties and drew attention to the importance of the consideration of political party systems as: "the organizational network of parties, (which) goes far beyond the party itself, for it includes all the space that a party is able to occupy de facto, and no matter under which form, in whatever setting." ${ }^{132}$ (Sartori, 2005, p. 8).

An additional essential aspect of Sartori's works ${ }^{33,34}$ (Sartori, 1976; 2005) is the introduction of the time dimension in political party system studies. The researcher underlined the significance of studies of: "historical patterns from which political parties originated." ${ }^{135}$ (Sartori, 2005, p. 10).

This idea of including the time dimension in the party system studies served as fertile ground for the emergence of recent studies on party systems dynamics and elaboration of Indexes measuring party systems volatility and fluidity ${ }^{36,37}$ (Pedersen, 1979; Pelizzo \& Nwokora, 2015).

Developed by Pedersen (1979): "Volatility Index shows the change in the share of votes (or seats) per party per election. It takes the sum of total net changes for each party, divided by $2 .{ }^{38}$ (Concha, 2014, p. 2).

However, the present Index of volatility has certain limitations; as units of analysis, it considers political parties but not party systems and: "the Index is calculated across all parties, not just for relevant parties. Thus, a party system can be moderately or highly volatile, although the vote returns of relevant parties remain stable." ${ }^{139}$ (Nwokora \& Pelizzo, 2018, p.108).

In 2015 the researchers Pelizzo and Nwokora elaborated on the Index of Party systems fluidity, which encompasses such components as "Frequency, Scope, and Variety of Party System change"40 (Nwokora \& Pelizzo, 2018). Through the calculation of:

"Frequency=Number of Party System Changes/ Number of Elections; Scope= Distance between the two most different types; Variety = number of Different Type Changes"41 (Nwokora \& Pelizzo, 2018, p. 107). This Index allows us to observe: "the dynamics of party systems"42 (Ibid, 2018, p. 102) change over time as well as the "stability of polity party systems. ${ }^{143}$ (Nwokora \& Pelizzo: 2018, p. 108)

Following Sartori's logic, the time dimension also plays a crucial role, as the Index allows capturing the dynamics of party system change. Therefore, it can be considered a useful analytical tool for party system change studies and comparative public policy studies. Namely measuring: "frequency, scope, and variety of party system"44 (Ibid, p.106) change: "during the historic period T1 through to T10"45 (Nwokora \& Pelizzo: 2018, p. 106) it is possible to calculate how countries $A$ and $B$ underwent different types of changes, e.g., let say, country A:

"underwent one type system change from the hegemonic type to two-partyism at T3, while country $B$ underwent two changes from moderate pluralism to polarized pluralism at T3, and from polarized pluralism back to moderate pluralism at T6."46 (Ibid, p.106).

Thus, considering not parties but party systems as units of analysis, the Index of fluidity ${ }^{4}$ (Ibid, 2018) allows capturing party system changes and conducting a comparative cross-country analysis covering different time-frameworks, countries, and regions.

Thinking about party systems, they are usually perceived as some static entities; however, the fluidity index allows for the exploration of the dynamics in party systems changes; this is in particular important in the context of developing countries where just before the election may appear different parties which after elections could stop functioning or are not that active as during the elections. One additional advantage of this Index is that it computes not the number of parties but the party system change based on consideration in changes, using Sartori terminology, of the number of relevant parties.

While concluding that party systems stability is essential for good governance, in his recent work $^{48}$ (Pelizzo, 2018) explores, also what are the factors affecting party system change. The study 
findings are: "ethnic fragmentation, urbanization, and development have no detectable impact on the stability of party systems, but poverty can greatly undermine the stability of party systems." 49 (lbid, p. 128).

Based on findings of Pelizzo and Stapenhurst $(2012)^{50}$ on legislative oversight and Index of Party System Fluidity ${ }^{51}$ (Pelizzo \&Nwokora, 2015), this work seeks to contribute to the existing literature by exploring the questions: how Legislative oversight affects Worldwide Governance Indicators (WGI) as well as how Party Systems Fluidity affects Legislative Oversight and WGI, in the context of Sub-Saharan African countries.

It is important to mention that the academic scholarship draws attention to the declining trust in Sub-Saharan African countries to the legislative institutions. As, for instance, the researchers, Cho (2010) pointed out: "In Africa, the neopatrimonial system significantly marginalizes the role of the legislature in government decision-making process"52 (Barkan 2009; van de Walle 2003 in Cho, 2010, p.10), which leads to the situation, when: "voters do not believe that they have a controlling ability to reward or punish elected officials"53 (Cho, 2010, p. 16). In this case, the importance gains the studies on how the development of the culture of "accountability" or using Schedler (1999) terminology "answerability"54 further to the development of good governance institutions in Sub-Saharan African countries. Our research, while analyzing IPU data (on the number of questions asked, questions answered, and $\%$ of questions) for 47 Sub-Saharan African countries, explores "both sides of answerability"55 (Schedler, 1999) of the accounting and accountable agencies, and its effects on World Governance Indicators.

\section{Data Analyses Methods}

For this research, we used the Inter-Parliamentary Union (IPU) dataset. "IPU is a global organization of national parliaments with 179 member Parliaments. The IPU is a unique open database platform, which allows us to study and to compare data on national parliaments." ${ }^{16}$ (IPU: 2020). This database comprises a broad range of data related to legislative oversight. To answer the first research question of how legislative oversight affects Worldwide Governance
Indicators, we take IPU data on 47 Sub-Saharan African countries, such as the number of written questions asked per year and the number of written questions answered the government per year.

Afterward, we calculated the percentage of written questions answered by the government per year. The IPU database allows scholars to explore the dynamics and changes in the data over time. For instance, for some countries, the data for 2012 were missing; we take the available data for some of the Sub-Saharan African countries for 2008, 2010, 2011, and 2013. The IPU database's advantage is that the data comes directly from national Parliaments, which makes the IPU database a valuable data source to study national parliaments globally, regionally, or locally. However, as the IPU official web-site states: "the level of information found may vary by chamber depending on the information provided by parliaments." 57 (IPU, 2020). Thus, such high dependence from the information provided by national parliaments could be considered one of the database's weaknesses. It is important to mention that the IPU database could serve just as one source of information; however for a more comprehensive in-depth study of legislative oversight in each case country, the application of other data sources (e.g., interviews, survey analysis, focus group discussions) might be essential.

Except the IPU data, we used also Worldwide Governance Indicators for each 47 Sub-Saharan African countries in all six dimensions of WGI. ${ }^{58}$ (The World Bank: 2012).

To explore the second and third research questions of this paper on the relationship between party systems fluidity and WGI as well as the fluidity and legislative oversight, the author used the Index of Party Systems Fluidity scores for each of 47 Sub-Saharan African countries; Prof. Riccardo Pelizzo kindly shared the data on scores of each of 47 Sub-Saharan African countries.

One of the apparent strengths in using the Index of Party System fluidity consists in the fact that in contrast to other Indexes on the volatility of political parties, it calculates not: "share of votes (or seats) per party per election"59 (e.g., Pedersen: 1979), but provides a more comprehensive and detailed 
indication of party system change dynamics in each of analyzed 47 Sub-Saharan African countries by calculating: "frequency, scope and variance"60 (Nwokora\& Pelizzo, 2018) of those changes.

We hypothesize that legislative oversight exert positive influence on WGI, while party systems fluidity (or instability) negatively affects both legislative oversight and WGI indicators.

We run the simple linear regression model based on IPU data on legislative oversight (questions asked, questions answered, and \% of questions) and WGI scores in all six dimensions in 47 Sub-Saharan African countries (2012). While to test remained two hypotheses on the impact of party systems fluidity on legislative oversight and WGI, to run a regression, we used the scores on party systems fluidity and, respectively, IPU data on legislative oversight and WGI scores for the same year 2012.

Though the author would like to draw the attention of scholars interested in the further elaboration of this topic, that a more comprehensive in-depth case study on the influence of legislative oversight and party system fluidity on WGI requires the application of rather mixed research methods as we believe contextual factors (political, economic, cultural: "shared norms, values, traditions"61 (Sartori, 2005) affecting the institution of parlamentarism and party system development might be hard to capture solely by statistical data analysis. Thus, it is possible to consider the present research as an initial step toward a more comprehensive study on legislative oversight and party systems fluidity influence on good governance indicators.

\section{Concluding Remarks and Main Findings}

In the beginning, we have pointed out that this paper seeks to explore the relationship between 1) legislative oversight and WGI; 2) Party Systems Fluidity and Legislative Oversight, and 3) Fluidity and WGI.

Our analysis reveals a strong positive correlation between Legislative Oversight and Worldwide Governance Indicators, meaning that the increase in legislative oversight leads to an increase of coefficients in each of six dimensions of governance indicators. These results signify that legislative oversight is an essential condition for government effectiveness.

Table 1:Correlations. Legislative Oversight and Worldwide Governance Indicators (sig.)

\begin{tabular}{lllllll}
\hline & $\begin{array}{l}\text { Control of } \\
\text { corruption }\end{array}$ & $\begin{array}{l}\text { Voice and } \\
\text { accountability }\end{array}$ & $\begin{array}{l}\text { Political } \\
\text { stability }\end{array}$ & $\begin{array}{l}\text { Rule } \\
\text { of law }\end{array}$ & $\begin{array}{l}\text { Government } \\
\text { effectiveness }\end{array}$ & $\begin{array}{l}\text { Regulatory } \\
\text { quality }\end{array}$ \\
\hline Number of written & .301 & $.429^{\star}$ & .219 & $.372^{\star}$ & $.478^{\star *}$ & $.423^{\star}$ \\
questions asked & $(.113)$ & $(.020)$ & $(.254)$ & $(.047)$ & $(.009)$ & $(.022)$ \\
Number of written & .246 & $.403^{*}$ & .229 & .352 & $.416^{*}$ & .416 \\
questions answered & $(.189)$ & $(.027)$ & $(.224)$ & $(.057)$ & $(.022)$ & $(.022)$ \\
$\%$ of written ques- & .280 & .059 & $.385^{*}$ & .333 & $.378^{*}$ & .247 \\
tions answered & $(.149)$ & $(.764)$ & $(.043)$ & $(.083)$ & $(.047)$ & $(.205)$ \\
\hline
\end{tabular}

**. Correlation is significant at the 0.01 level (2-tailed)

*. Correlation is significant at the 0.05 level (2-tailed).

Questions asked, questions answered, and \% of questions are: "positively and significantly related to the various indicators of governance." ${ }^{162}$ (Pelizzo: 2020, p. 265). We hypothesized that party systems' fluidity might impact the legislative oversight. Our regression model results show a negative correlation between fluidity and legislative oversight, namely, the higher is party systems fluidity (instability), the lower falls the coefficients on legislative oversight. This finding suggests that: "an increase in a number of political parties"63 (Arsenault, 2017, p. 147) presented in the Parliament does not lead to an increase of legislative oversight effectiveness. The high number of political parties may lead to 
constant clashes, disputes, and instability of the system. For instance, the researcher Amuvo (2010) emphasizes that:

"During the general elections in 2007, Nigeria had no fewer than 50 political parties, many of them very small and with no pretentions of being able to fulfill the constitutional requirements...Parties are hardly present, let alone active on the ground. Members, on their part, are largely fictitious entities." 64 (Amuvo in Lawson: 2010, pp. 90-91). Therefore, the general belief that a greater number of political parties lead to democratic development sound rather naïve. The study findings suggest that the stability of party systems is an essential pre-condition for legislative oversight effectiveness.

Table 2: Correlations. Fluidity and Legislative Oversight (sig.)

\begin{tabular}{llll}
\hline & $\begin{array}{l}\text { Number of written } \\
\text { questions asked }\end{array}$ & $\begin{array}{l}\text { Number of written } \\
\text { questions answered }\end{array}$ & $\begin{array}{l}\text { Percentage of written } \\
\text { questions answered }\end{array}$ \\
\hline Fluidity & -.276 & -.308 & $-.400^{\star}$ \\
& $(.148)$ & $(.098)$ & $(.035)$ \\
\hline
\end{tabular}

*. Correlation is significant at the 0.05 level (2-tailed).

Our final table demonstrates statistically significant results showing a negative relationship between party system fluidity and WGI, signifying that an increase in party systems fluidity leads to the decrease in all six WGI dimensions. These findings may serve as an additional contribution to Pelizzo and Nwokora (2017) findings that: "unstable party systems undermine the quality of democracy... (therefore) stable party systems are desirable, but some forms of system change are also beneficial to democratic quality." ${ }^{\circ 5}$ (Pelizzo \& Nwokora: 2017, p. 524)

Table 3: Fluidity and Worldwide Governance Indicators (sig.)

\begin{tabular}{llllllll}
\hline & Fluidity & $\begin{array}{l}\text { Control of } \\
\text { corruption }\end{array}$ & $\begin{array}{l}\text { Voice and } \\
\text { accountability }\end{array}$ & $\begin{array}{l}\text { Political } \\
\text { stability }\end{array}$ & $\begin{array}{l}\text { Rule } \\
\text { of law }\end{array}$ & $\begin{array}{l}\text { Government } \\
\text { effectiveness }\end{array}$ & $\begin{array}{l}\text { Regulatory } \\
\text { quality }\end{array}$ \\
\hline Fluidity & 1.0 & $-.384^{* *}$ & $-.296^{*}$ & $-.425^{* *}$ & $-.351^{*}$ & $-.465^{* *}$ & -.363 \\
& & $(.008)$ & $(.046)$ & $(.003)$ & $(.017)$ & $(.001)$ & $(.013)$ \\
\hline
\end{tabular}

**. Correlation is significant at the 0.01 level (2-tailed)

*. Correlation is significant at the 0.05 level (2-tailed)

In summarizing our findings, it is important to mention that in/stability of political party systems is quite an ambiguous notion. However, the Index of party systems fluidity elaborated by Nwokora \& Pelizzo recently in 2015 may serve as a useful analytic tool for capturing the dynamics of party system changes in different countries of the world. Indeed, legislative oversight and overall government effectiveness depend on many factors, except party systems' stability also from other political, economic, and cultural factors.
Therefore, Duvergers "an atomistic nuclear" approach in studying parties and party systems as well as Sartori's "Parteiraum" (party space) approach of viewing party systems as: "space of de-facto of the interaction of political parties"66 (Sartori, 2005, p. 8) both are justified.

Our IPU dataset analysis has shown that Parliamentarians rarely address the government and do not use the oversight at full capacity; therefore, many studies, both qualitative and quantitative, 
needs to be done to fill the exiting gap the literature to define those factors (political, economic and cultural) that hinder legislative oversight effectiveness in SubSaharan African countries. At the same time, it is also possible again to draw the attention of scholars to the Index of Party System Fluidity (2015), which allows the researchers to analyze the dynamics of party system change of different countries at different historical timeframes. Therefore, we believe it is possible to expect comparative studies that will capture party system changes using the Index of fluidity shortly.

\section{Acknowledgment}

The author would like to express sincere gratitude to Prof. Dr. Riccardo Pelizzo, who kindly shared collected data sources on party systems fluidity in 47 Sub-Saharan African countries and the Graduate School of Public Policy (GSPP), Nazarbayev University (Nur-Sultan, Kazakhstan). A special note of thank you, the author expresses to two anonymous reviewers for highly valuable remarks and suggestions for the paper improvement.

\section{Funding}

The author received no financial support for the authorship and publication of this article.

\section{Conflict of Interest}

The author declares no conflict of interest.

\section{References}

1. The World Bank. (2019). Worldwide Governance Indicators. Retrieved from https://info.worldbank.org/governance/wgi/.

2. Pelizzo, R. (2020). Good Governance and Party System Change. Politics and Policy, 48(2), 265-287. https://doi.org/10.1111/ polp. 12347.

3. Van Biezen, I., \& Kopecký, P. (2007). The state and the parties: Public funding, public regulation and rent-seeking in contemporary democracies. Party Politics, 13(2), 235-254. https://doi.org/10.1177/1354068807073875.

4. Transparency International. (2019). In Whose Interest? Political Integrity and Corruption in Africa. Retrieved from https:// www.transparency.org/news/feature/political_ corruption_and_political_integrity_in_africa

5. Kimathi, L. (2010). Toward democratic consolidation in Kenya: the role of political parties. In K. Lawson, L. Sindjoun, \&Simms, M. (Eds.), Political Parties and Democracy. Africa and Oceania. (pp. 37-53), Vol. IV, Santa Barbara, California, Denver, Colorado, Oxford, England: Praeger.

6. Stapenhurst, F., Jacobs, K. \& Pelizzo, R. (2014). Corruption and Legislatures, MesoLevel Solutions for a Macro-Level Problem, Public Integrity, 16:3, pp. 285-304. https://doi. org/10.2753/PIN1099-9922160304.

7. Pelizzo, R., \& Stapenhurst, R. (2004). Tools for Legislative Oversight: An Empirical
Investigation. World Bank Policy Research Working Paper Quaderni Di Scienza Political, 3388(1), 175-188. Retrieved from http://econ. worldbank.org.

8. Pelizzo, P. \& Stapenhust, F. (2013). The Dividends of Good Governance in Policy Studies Organization. Poverty \& Public Policy. Vol.5, Issue 4. https://onlinelibrary.wiley.com/ doi/pdf/10.1002/pop4.49.

9. Sartori, G. (2005). Party Types, Organization and Functions, West European Politics, 28:1, 5-32, DOI: 10.1080/0140238042000334268 http://citeseerx.ist.psu.edu/viewdoc/downlo ad;jsessionid=3F4EA356ECCD2983F9AF5 31DA5F717FD?doi=10.1.1.602.3134\& $\mathrm{rep}=r$ ep1\&type=pdf.

10. Nwokora, Z. \& Pelizzo, R. (2015). The Political Consequences of Party System Change. Politics \& Policy 43 ( 4): 453- 473. Retrieved from http://onlinelibrary.wiley.com/ doi/10.1111/polp.12124/full.

11. Kinyondo, A., Pelizzo, R. \& A. Umar. (2015). A Functionalist Theory of Oversight. African Politics and Policy. (online journal) https:// www.africanpoliticsandpolicy.com/?p=845.

12. Pelizzo, R., \& Stapenhurst, R. (2004). Tools for Legislative Oversight: An Empirical Investigation. World Bank Policy Research Working Paper Quaderni Di Scienza Politica, 3388(1), 175-188. Retrieved from http://econ. worldbank.org. 
13. Pelizzo, R., \& Stapenhurst, R. (2004). Tools for Legislative Oversight: An Empirical Investigation. World Bank Policy Research Working Paper Quaderni Di Scienza Political, 3388(1), 175-188. Retrieved from http://econ. worldbank.org.

14. Chohan, U. W. (2017). Legislative Oversight of Bureaucracy. In A. Farazmand (Ed.), Global Encyclopedia of Public Administration, Public Policy, and Governance (pp. 1-5). Springer International Publishing. https://doi. org/10.1007/978-3-319-31816-5_698-1.

15. Chohan, U. W. (2017). Legislative Oversight of Bureaucracy. In A. Farazmand (Ed.), Global Encyclopedia of Public Administration, Public Policy, and Governance (pp. 1-5). Springer International Publishing. https://doi. org/10.1007/978-3-319-31816-5_698-1.

16. Stapenhurst, R., Jacobs, K. \& T. C. Eboutou. (2019). Developing an index of Ex-post parliamentary oversight of public finance, The Journal of Legislative Studies, 25:1, 119-142, DOI: 10.1080/13572334.2019.1572617.

17. Stapenhurst, R., Jacobs, K. \& T. C. Eboutou. (2019). Developing an index of Ex-post parliamentary oversight of public finance, The Journal of Legislative Studies, 25:1, 119-142, DOI: 10.1080/13572334.2019.1572617

18. Stapenhurst, F. Jacobs, K. \& Pelizzo, R. (2014). Corruption and Legislatures, Public Integrity, 16:3, 285-304, DOI: 10.2753/ PIN1099-9922160304

19. World Bank Institute. (2013). Improving Democratic Accountability Globally. A Handbook for legislators on congressional oversight in presidential systems. GOPAC. Retrieved from http://gopacnetwork.org/Docs/ CO_Handbook_EN.pdf

20. Pelizzo, R. \& Stapenhurst, R. (2004). Tools of Legislative Oversight: An Empirical Investigation. Singapore Management University. Research Collection School of Social Sciences. Retrieved from https:// ink.library.smu.edu.sg/cgi/viewcontent. cgi? article $=1043 \&$ context=soss_research

21. Pelizzo, R. and Stapenhurst, R. (2004). Tools for Legislative Oversight: An Empirical Investigation. Research Collection School of Social Sciences. Paper 44. Retrieved from: https://ink.library.smu.edu.sg/soss_ research/44

22. The World Bank Institute. (2013). Improving Democratic Accountability Globally. A Handbook for legislators on congressional oversight in presidential systems. GOPAC. Retrieved from http://gopacnetwork.org/Docs/ CO_Handbook_EN.pdf

23. Kinyondo, A., Pelizzo, R. \& A. Umar. (2015). A Functionalist Theory of Oversight. African Politics and Policy. (Online journal) https:// www.africanpoliticsandpolicy.com/?p=845

24. Sartori, G. (2005). Party Types, Organization and Functions, West European Politics, 28:1, 5-32, DOI: 10.1080/0140238042000334268 http://citeseerx.ist.psu.edu/viewdoc/downlo ad;jsessionid=3F4EA356ECCD2983F9AF5 31DA5F717FD?doi=10.1.1.602.3134\&rep $=r$ ep1\&type=pdf

25. Duverger, M. (1954). Political parties, their organization and activity in the modern state. London, Methuen; New York, Wiley in Sartori, G. (2005). Party types, organization and functions. West European Politics, 28(1), 5-32. https://doi. org/10.1080/0140238042000334268

26. Novák, M. and Cadenza Academic Translations (2015) Competitive party systems: Where do Duverger and Sartori diverge? Revue française de science politique (English Edition), Vol. 65, No. 3 (2015), pp. 69- 88. https://www.jstor.org/stable/10.2307/ revfranscipoleng.65.3.69

27. Novák, M. and Cadenza Academic Translations (2015) Competitive party systems: Where do Duverger and Sartori diverge? Revue française de science politique (English Edition), Vol. 65, No. 3 (2015), pp. 69- 88. https://www.jstor.org/stable/10.2307/ revfranscipoleng.65.3.69 .

28. Pasquino, G. (2005). The political science of Giovanni Sartori. European Political Science, 4(1), 33-41. https://doi.org/10.1057/palgrave. eps.2210003.

29. Nwokora, Z., \& Pelizzo, R. (2015). The Political Consequences of Party System Change. Politics and Policy, 43(4), 453-473. https:// doi.org/10.1111/polp.12124.

30. Nwokora, Z., \& Pelizzo, R. (2015). The Political Consequences of Party System Change. Politics and Policy, 43(4), 453-473. https:// 
doi.org/10.1111/polp.12124.

31. Pelizzo, R.\& Nwokora, Z. (2016). Bridging the Divide: Measuring Party System Change and Classifying Party Systems. Politics \& Policy 44 (6): 1017- 1052. http://onlinelibrary.wiley. com/doi/10.1111/polp.12188/full.

32. Sartori, G. (2005) Party Types, Organisation and Functions, West European Politics, 28:1, 5-32, DOI: $10.1080 / 0140238042000334268$ http://citeseerx.ist.psu.edu/viewdoc/downlo ad;jsessionid=3F4EA356ECCD2983F9AF5 31DA5F717FD?doi=10.1.1.602.3134\&rep $=r$ ep1\&type=pdf.

33. Sartori, G (1976). Parties and Party Systems: A Framework for Analysis. ECPR Press, 2005.

34. Sartori, G. (2005) Party Types, Organisation and Functions, West European Politics, 28:1, 5-32, DOI: 10.1080/0140238042000334268 http://citeseerx.ist.psu.edu/viewdoc/downlo ad;jsessionid=3F4EA356ECCD2983F9AF5 31DA5F717FD?doi=10.1.1.602.3134\& $\mathrm{rep}=\mathrm{r}$ ep1\&type=pdf.

35. Sartori, G. (2005) Party Types, Organisation and Functions, West European Politics, 28:1, 5-32, DOI: 10.1080/0140238042000334268 http://citeseerx.ist.psu.edu/viewdoc/downlo ad;jsessionid=3F4EA356ECCD2983F9AF5 31DA5F717FD?doi=10.1.1.602.3134\& $\mathrm{rep}=\mathrm{r}$ ep1\&type=pdf.

36. Pedersen, M. excerpted from 'The Dynamics of European Party Systems: Changing Patterns of Electoral Volatility', European Journal of Political Research, 7/1 (1979), 1-26. Copyright 1979. Reprinted with permission of Kluwer Academic Publisher. Retrieved from: http://janda.org/c24/Readings/Pedersen/ Pedersen.htm.

37. Pelizzo, R \& Nwokora, Z. (2015). The political consequences of party system change. Politics and Policy 43.4 (2015): 453-473. DOI: 10.1111/polp.12124.

38. Concha, E. O. (2014). Institutionalization of party systems: A cross-regional approach using the Weighted Volatility Index. 23. Prepared for the Political Studies Association $64^{\text {th }}$ Annual International Conference, Manchester, April 14-16, 2014.

39. Nwokora, Z. \& Pelizzo, P. (2018). Measuring Party System Change: A Systems Perspective in Political Studies, 1-19. Retrieved from: https://journals.sagepub.com/doi/ full/10.1177/0032321717710568.

40. Nwokora, Z. \& Pelizzo, P. (2018) Measuring Party System Change: A Systems Perspective in Political Studies, 1-19.Retrieved from: https://journals.sagepub.com/doi/ full/10.1177/0032321717710568.

41. Nwokora, Z. \& Pelizzo, P. (2018) Measuring Party System Change: A Systems Perspective in Political Studies, 1-19.Retrieved from: https://journals.sagepub.com/doi/ full/10.1177/0032321717710568.

42. Nwokora, Z. \& Pelizzo, P. (2018). Measuring Party System Change: A Systems Perspective in Political Studies, 1-19.Retrieved from: https://journals.sagepub.com/doi/ full/10.1177/0032321717710568.

43. Nwokora, Z. \& Pelizzo, P. (2018). Measuring Party System Change: A Systems Perspective in Political Studies, 1-19.Retrieved from: https://journals.sagepub.com/doi/ full/10.1177/0032321717710568.

44. Nwokora, Z. \& Pelizzo, P. (2018) Measuring Party System Change: A Systems Perspective in Political Studies, 1-19.Retrieved from: https://journals.sagepub.com/doi/ full/10.1177/0032321717710568.

45. Nwokora, Z. \& Pelizzo, P. (2018) Measuring Party System Change: A Systems Perspective in Political Studies, 1-19.Retrieved from: https://journals.sagepub.com/doi/ full/10.1177/0032321717710568.

46. Nwokora, Z. \& Pelizzo, P. (2018). Measuring Party System Change: A Systems Perspective. Political Studies, 1-19.Retrieved from: https://journals.sagepub.com/doi/ full/10.1177/0032321717710568.

47. Nwokora, Z. \& Pelizzo, P. (2018). Measuring Party System Change: A Systems Perspective. Political Studies, 1-19.Retrieved from: https://journals.sagepub.com/doi/ full/10.1177/0032321717710568.

48. Pelizzo, R. (2018). The Determinants of Party System Change in Sub-Saharan Africa. Jurnal IImu Pemerintahan, 8 (2), 124-129.

49. Pelizzo, R. (2018). The Determinants of Party System Change in Sub-Saharan Africa. Jurnal IImu Pemerintahan, 8 (2), 124-129.

50. Pelizzo, R. \& Stapenhurst, R. (2012). Legislative Oversight and the Quality of 
Democracy. Retrieved from: https://ssrn. com/abstract=2105585 or http://dx.doi. org/10.2139/ssrn.2105585.

51. Pelizzo, R \& Nwokora, Z. (2015). The political consequences of party system change. Politics and Policy 43.4 (2015): 453-473. DOI: 10.1111/polp.12124.

52. Cho, W. (2010). Citizens' Perceptions of Government Responsiveness in Africa: Do Electoral Systems and Ethnic Diversity Matter? Comparative Political Studies, 43(12), 1650-1674. https://doi. org/10.1177/0010414010374019.

53. Cho, W. (2010). Citizens' Perceptions of Government Responsiveness in Africa: Do Electoral Systems and Ethnic Diversity Matter? Comparative Political Studies, 43(12), 1650-1674. https://doi. org/10.1177/0010414010374019.

54. Schedler (1999). Conceptualizing Accountability. Self-Restraining State: Power and Accountability in New Democracies. In Schedler, A., Diamond, L. and Plattner, M. F.Boulder (Eds.), London: Lynne Rienner Publishers. Retrieved from http://works. bepress.com/andreas_schedler/22/.

55. Schedler, A. (1999). Conceptualizing Accountability. Self-Restraining State: Power and Accountability in New Democracies. In Schedler, A., Diamond, L. and Plattner, M. F.Boulder (Eds.). London: Lynne Rienner Publishers. Retrieved from http://works. bepress.com/andreas_schedler/22/.

56. Inter-Parliamentary Union. (2020). Parline database. Retrieved from https://data.ipu.org/.

57. Inter-Parliamentary Union. (2020). Parline database. Retrieved from https://data.ipu.org/.

58. The World Bank. (2012). Worldwide Governance Indicators. Retrieved from: https://info.worldbank.org/governance/wgi/.

59. Concha, E. O. (2014). Institutionalization of party systems: A cross-regional approach using the Weighted Volatility Index. 23. Prepared for the Political Studies Association 64th Annual International Conference, Manchester. Retrieved from https://www. academia.edu/7111579/Institutionalization of_party_systems_cross_regional_ approach_Weighted_Volatility_Index_PSA.

60. Nwokora, Z., \& Pelizzo, R. (2018). Measuring Party System Change: A Systems Perspective. Political Studies, 66(1), 100-118. https://doi. org/10.1177/0032321717710568.

61. Sartori, G. (2005). Party Types, Organisation and Functions, West European Politics, 28:1, 5-32, DOI: 10.1080/0140238042000334268 http://citeseerx.ist.psu.edu/viewdoc/downlo ad;jsessionid=3F4EA356ECCD2983F9AF5 31DA5F717FD?doi=10.1.1.602.3134\&rep=r ep1\&type=pdf.

62. Pelizzo, R. (2020). Good Governance and Party System Change. Politics and Policy. https://onlinelibrary.wiley.com/doi/ full/10.1111/polp.12347.

63. Arsenault M.P. (2017) A Political Approach to Explaining Variation in Capitalist Systems. In: The Effects of Political Institutions on Varieties of Capitalism. Palgrave Macmillan, Cham. https://doi.org/10.1007/978-3-319-50892-4_2

64. Amuvo, A. (2010). Stuck at the gate of political transition? Dynamics of political parties and democratization in Nigeria. In K. Lawson, L. Sindjoun, \&Simms, M. (Eds.), Political Parties and Democracy. Africa and Oceania. (pp. 81-103) Vol. IV, Santa Barbara, California, Denver, Colorado, Oxford, England: Praeger.

65. Pelizzo, R. \& Nwokora, Z. (2017). Party System Change and the Quality of Democracy in East Africa. AGDI Working Paper, No. WP/17/051, African Governance and Development Institute (AGDI), Yaoundé.

66. Sartori, G. (2005). Party Types, Organisation and Functions. West European Politics, 28:1, 5-32, DOI: 10.1080/0140238042000334268 Retrieved from http://citeseerx.ist.psu.edu/ viewdoc/download;jsessionid=3F4EA356E CCD2983F9AF531DA5F717FD?doi=10.1.1 $.602 .3134 \&$ rep $=$ rep $1 \&$ type $=$ pdf. 